\title{
Using archetypoid analysis to classify institutions and faculties of economics
}

\author{
Klaus Wohlrabe ${ }^{1}$ (D) Sabine Gralka ${ }^{2}$ (D)
}

Received: 21 July 2019 / Published online: 8 February 2020

(C) The Author(s) 2020

\begin{abstract}
We use archetypoid analysis as a new tool to categorize institutions and faculties of economics. The approach identifies typical characteristics of extreme (archetypal) values in a multivariate data set. Each entity under investigation is assigned relative shares of the identified archetypoid, which show the affiliation of the entity to the archetypoid. In contrast to its predecessor, the archetypal analysis, archetypoids always represent actual observed units in the data. The approach therefore allows to classify institutions in a rarely used way. While the method has been recognized in the literature, it is the first time that it is used in higher education research and as in our case for institutions and faculties of economics. Our dataset contains seven bibliometric indicators for 298 top-level institutions obtained from the RePEc database. We identify three archetypoids, which are characterized as the top-, the low- and the medium-performer. We discuss the assignment of shares of the identified archetypoids to the institutions in detail. As a sensitivity analysis we show how the classification changes when for four and five archetypoids are considered.
\end{abstract}

Keywords Archetypoid analysis - Classification $\cdot$ RePEc $\cdot$ Faculty of economics · Economic institutions

JEL Classification C38 $\cdot$ I2 $1 \cdot$ I 23

\section{Introduction}

The performance measurement of research institutions and universities takes up an increasing role in current policy discussions. While the associated debate on rankings and efficiency evaluations has been taken up in the scientific literature (Bolli et al. 2016; Gnewuch and Wohlrabe 2018; Gralka 2018) the underlying classification of institutions seems to have been largely neglected. However, a classification-a creation of a framework for

Klaus Wohlrabe

wohlrabe@ifo.com

Sabine Gralka

sabine.gralka@tu-dresden.de

1 Ifo Institute, Center for Macroeconomics and Surveys, Munich, Germany

2 Faculty of Business and Economics, TU Dresden, Dresden, Germany 
diverse institutions - is one of the most challenging tasks a researcher can be confronted with (Hazelkorn 2007). A well-known, recurrently discussed grouping is the Carnegie Classification, which has served as a framework for American colleges and universities for more than 30 years (Pike and Kuh 2005). Although the system has its advantages, the framework is context specific and quite complex. Most researchers, especially if interested in a country without an already existing classification structure, require a simpler method for the classification of institutions. Even more so if sub-groups, as faculties, are the evaluation unit of interest.

We argue that archetypal analysis offers a suitable and straight-forward way to classify institutions based on observed data. The method was originally formulated by Cutler and Breiman (1994) and imitates the human tendency of representing a group of objects by its extreme elements (Davis and Love 2010; Epifanio 2016). The aim of the method is to find pure types (the archetypes) in such a way that the other observations are a mixture of them. Hence, archetypes can be seen as data-driven extreme points. This makes the approach an interesting tool for researches, in particular if policy recommendations are striven for. Computationally, the approach is data-driven, and requires the factors to be probability vectors: these make archetypal analysis a computationally demanding tool, yet brings better interpretability. However, the classic archetypal analysis has an important drawback: archetypes are a combination of the sampled units, but they are not necessarily observed institutions. This situation can cause interpretation problems for analysts. In order to address this limitation, a new archetypal concept was introduced: the archetypoid, which is a real (observed) archetypal case (Vinué et al. 2015). Thus, archetypoids allow an intuitive understanding of the results even for non-experts (Thurau et al. 2012).

Archetypal analysis has aroused the interest of researchers working in various fields, such as remote sensing (Chan et al. 2003), climate (Steinschneider and Lall 2015), machine learning (Mørup and Hansen 2012; Seth and Eugster 2016), neuroscience (Hinrich et al. 2016), navigation (Feld et al. 2015) and sports (Seth and Eugster 2016). The same applies for the archetypoid analysis, which was used for the evaluation within fields such as astrophysics (Sun et al. 2017), sports (Vinué and Epifanio 2017) and the financial stock market (Moliner and Epifanio 2018). Building upon the study by Seiler and Wohlrabe (2013) who evaluate scientists, we look at economics faculties and institutions within the present study. ${ }^{1}$ In contrast to the previous study, we employ the archetypoid instead of the archetypal analysis, given the more intuitive understanding of the former method. Parallel to the authors we employ RePEc (Research Papers in Economics) data for our study.

A short description of the method of analysis is provided in the next section, followed by an examination of the dataset. The presentation of the results is complemented by a sensitivity analysis that pays special attention to the number of archetypoids considered. A concluding section brings together the main findings and offers several suggestions for future research.

\footnotetext{
${ }^{1}$ For simplicity we frequently refer to institutions of economics (instead of institutions and faculties) henceforth.
} 


\section{Methodology}

In this section archetypal analysis, as the basis for identifying archetypoids, is outline first. Consider an $N \times m$ matrix, where $\boldsymbol{X}$ represents a multivariate data set with $N$ observations (in our case faculties and institutions) and $m$ characteristics (e.g. works, citations, downloads, etc.). For a given number of archetypes $k$, the algorithm finds the matrix $\boldsymbol{Z}$ by minimizing the residual sum of squares

$$
\mathrm{RSS}=\left\|\mathrm{X}-\alpha \mathrm{Z}^{\prime}\right\|_{2}
$$

where $\alpha$ denotes the coefficients of the archetypes with dimensions $N \times k$ and $\|\bullet\|_{2}$ the $L_{2}$ norm. Equation (1) is minimized subject to the following constraints

$$
\alpha_{i j} \geq 0 \quad \text { and } \sum_{j=1}^{k} \alpha_{i j}=1
$$

for $i=1, \ldots N$. The $k$ archetypes are then convex combinations of the data, i.e.

$$
Z=X^{\prime} \beta
$$

where $\beta$ is an $N \times k$ matrix. The constrains

$$
\beta_{i j} \geq 0 \quad \text { and } \quad \sum_{j=1}^{k} \beta_{i j}=1
$$

are imposed for estimating Eq. (2). The last statement shows that the archetypes are convex combinations of the original data set $\boldsymbol{X}$. Equations (1) and (2) form the basis for the estimation algorithm: it alternates between finding the best $\alpha$ for given archetypes $\boldsymbol{Z}$ and finding the best archetypes for $\boldsymbol{Z}$ given $\boldsymbol{\alpha}$. Cutler and Breiman (1994) popularized this approach as alternating least squares.

A consequence of the approach outlined in Eqs. (1) and (2) is that archetypes are not represented by real observed units in the data set. Vinué et al. (2015) proposed a slight modification of the original approach and introduced the term archetypoids. They proposed to modify the constrains for $\beta$ in the following way

$$
\begin{aligned}
& \sum_{j=1}^{k} \beta_{i j}=1 \quad \text { with } \boldsymbol{\beta}_{i j} \in\{0,1\}, \text { i.e. } \boldsymbol{\beta}_{i j}=1 \text { for and only one } \boldsymbol{j} \text { and } \\
& \boldsymbol{\beta}_{i j}=0 \text { otherwise. }
\end{aligned}
$$

This condition ensures that $Z$ must be a point in the dataset. Hence, archetypoids can be viewed as extreme points in the data.

A central question for the analysis concerns the optimal number of archetypoids for a given data set. In contrast to principal component analysis, archetypoid analysis allows to extract more archetypoids than dimensions of the data set. There is no formal rule for the determination. In praxis, usually the "elbow" criterion for the Residual Sum of Squares (RSS) curve, the so-called scree-plot, is applied. A "flattening" of the curve suggests a potential value of $k$. We are aware that this choice is arbitrary. We therefore suggest investigating several numbers of archetypoids and to take a look on the concrete 
interpretation of each. Our experience is the more archetypoids are considered the more similar some archetypoids become.

For a detailed description of archetypoid analysis including computational issues, we refer to Vinué et al. (2015). We extract the archetypoids using the R package Anthropometry version 1.13 by Vinué (2017). As our indicators (described in the next section) exhibit different scales we standardize them prior to determining the archetypoids. We do so by subtracting the mean and dividing by the standard deviation.

\section{Data}

We illustrate archetypoid analysis using a large data set of institutions and faculties of economics from the RePEc (Research Papers in Economics) website (http://www.repec .org). In socio-economic sciences RePEc has become an essential source for the spread of knowledge and ranking of individual authors and academic institutions. ${ }^{2}$ RePEc is based on the active participation principle, that is authors, institutions and publishers register and provide information to the network. This approach has the main advantage that a clear assignment of works and citations to authors and articles is possible without any problems of name disambiguation. Each registered author sets a share by which he or she is affiliated with an institution. In case of no self-setting, RePEc calculates shares based on the other affiliated members of the institution. The scores are allocated to the corresponding institution accordingly. In the following, we call these accumulated author shares full-time equivalents (FTE), given that an institution with 10 authors, who all identify themselves with $80 \%$, would have the same accumulated author share (or FTE) as an institution with 8 authors who all identify with $100 \%$.

RePEc has become quite a success, as of December 2019 there were 2.8 million pieces of research from 3200 journals and 5000 working paper series. Additionally, more than 55,000 authors and 14,000 institutions from 101 countries are listed on the website.

RePEc currently offers 37 rankings for institutions and faculties based on bibliometric data which are shown in Table 1. There are five main categories: number of (published) works, citations, citing authors, journal pages, and RePEc access statistics. Each of these main categories can be combined with different weighting schemes: simple or recursive impact factors, number of authors and combinations of them. In the category "distinct number of works" different versions of a paper are counted only once. Published work is counted only if, first the publisher provides the meta data to RePEc and second, the author assigns the work to his/her account. Table 1 reveals that there is a focus on citations both directly and indirectly. In 14 rankings, citations are counted with quality and time adjustments. Moreover, citations matter indirectly through the different impact factors. The simple impact factor captures the quality level of a journal and is similarly defined as the impact factor published by Thomson Reuters Journal Citation Reports.

We downloaded the 37 publicly available rankings from the RePEc website in early December 2019, where the data refers to the November ranking. For these rankings only the top 5\% of world-wide institutions are available. The bibliometric scores are highly correlated, as shown by Zimmermann (2013) and Seiler and Wohlrabe (2013) in case of

\footnotetext{
${ }^{2}$ RePEc data has been used in bibliometric research in Rath and Wohlrabe (2016), Gnewuch and Wohlrabe (2018), Hsieh et al. (2018) or Bornmann and Wohlrabe (2019) among others.
} 
Scientometrics (2020) 123:159-179

163

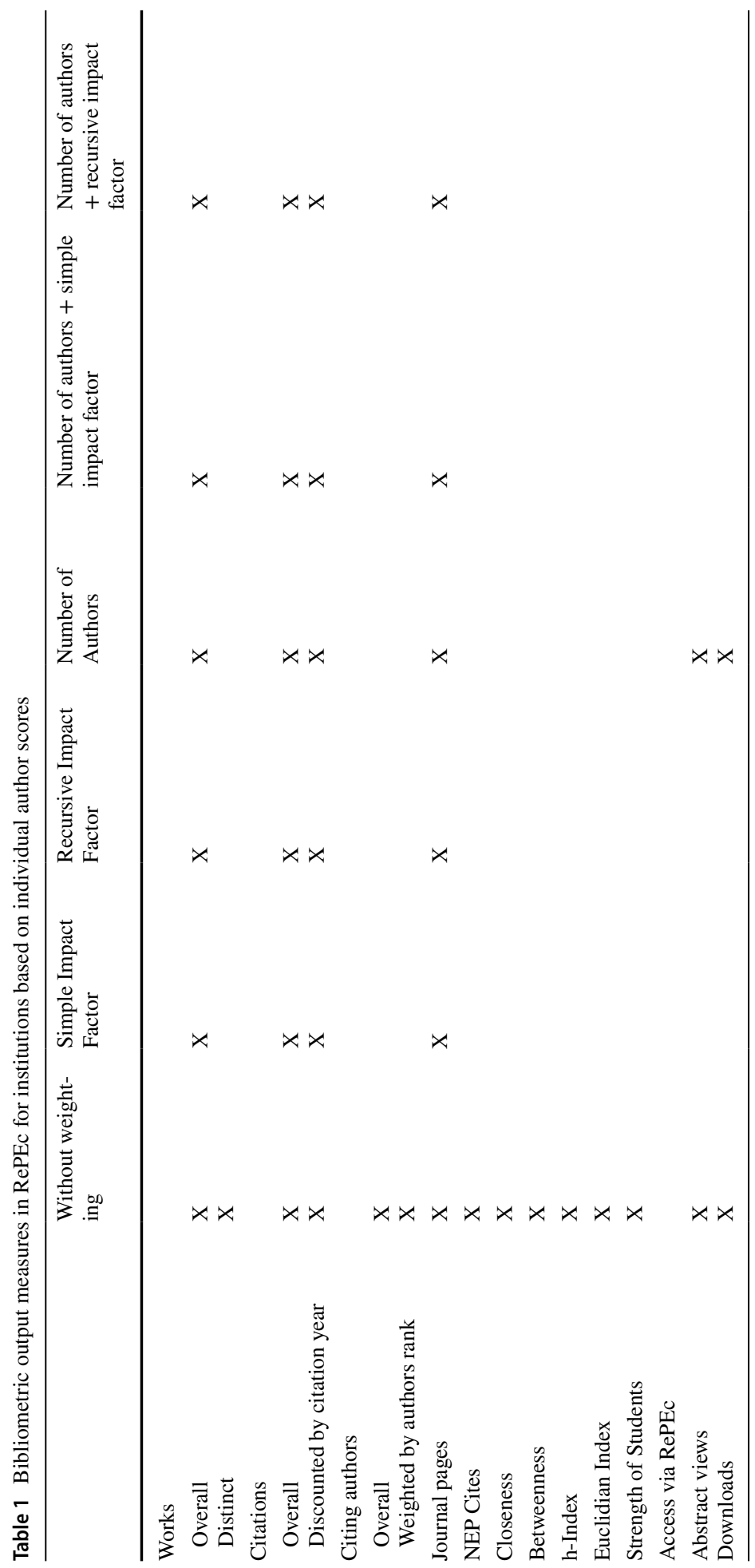

Springer 
authors and by Gnewuch and Wohlrabe (2018) for economic institutions and faculties. We therefore follow the idea of Seiler and Wohlrabe (2013) and use only a subset of the 37 rankings which can be captured in four groups. These are the following seven ones:

- Published work, which includes working papers, books, software codes, and chapters

- Number of distinct works, unweighted

- Number of distinct works, weighted by simple impact factor

- Citations, which represent the impact of an author

- Number of citations, unweighted

- Number of citations, weighted by the simple impact factor

- Pages, which accounts for the published articles

- Number of pages, unweighted

- Number of pages, weighted by the simple impact factor

- Number of downloads, which shows the access

For each of our $\mathrm{m}=7$ bibliometric indicators we collected the corresponding institutions and faculties where the scores were publicly available. We ended up with $\mathrm{N}=298$ which can be found in the "Appendix", Table 5. The list comprises both faculties (as for example the Economics department at the MIT), institutions (ifo Institute), central banks (ECB) or scientific networks (NBER).

The descriptive statistics for the original and normalized indicators can be found in Table 2. On average 77 scientists are employed at a faculty or university. The corresponding

Table 2 Descriptive statistics

\begin{tabular}{lrrrr}
\hline 298 Observations & \multicolumn{1}{l}{ Mean } & SD & \multicolumn{1}{l}{ Min } & Max \\
\hline Absolut & & & & \\
Number of distinct works & 1704.62 & 1212.26 & 662.21 & $11,623.95$ \\
$\quad$ Weighted by simple impact factor & $31,015.22$ & $27,596.89$ & 7340.26 & $223,360.84$ \\
Number of citations & $26,925.12$ & $29,890.69$ & 5741.35 & $248,982.71$ \\
$\quad$ Discounted by citation age & 6007.97 & 6380.96 & 1366.55 & $49,248.27$ \\
Number of pages & $16,484.67$ & $10,555.85$ & 6443.01 & $90,451.84$ \\
$\quad$ Weighted by simple impact factor & $278,398.41$ & $252,671.95$ & $65,909.15$ & $1,936,830.56$ \\
Number of downloads & 8882.81 & 7595.53 & 2782.43 & $65,784.85$ \\
$N$ & 76.71 & 80.80 & 19.00 & 902.00 \\
Full-time equivalents & 59.61 & 51.82 & 13.59 & 473.62 \\
Normalized & & & & 7.90 \\
Number of distinct works & 31.96 & 11.80 & 7.90 & 3344.34 \\
$\quad$ Weighted by simple impact factor & 651.45 & 528.10 & 39.05 & 4158.03 \\
Number of citations & 570.04 & 595.23 & 26.49 & 822.45 \\
Discounted by citation age & 124.24 & 121.21 & 6.10 & 774.08 \\
Number of pages & 321.85 & 132.86 & 71.71 & $33,123.79$ \\
$\quad$ Weighted by simple impact factor & 5996.28 & 5227.81 & 308.04 & 724.75 \\
Number of downloads & 171.15 & 105.35 & 19.58 & \\
\hline
\end{tabular}


full-time equivalent is with about 60 people slightly lower. The largest institute is the research network Institute of Labor Economics (IZA) and the smallest the economics faculty is located at the Johns Hopkins University, with respectively 902 and 19 affiliated economists. An average economics institution has published around 1700 articles, which contain around 16,500 pages in (refereed) journals and were downloaded around 8900 times. The typical institution has received around 26,900 citations. It is thereby important to bear in mind, that the numbers describe stock levels (up to November 2019), which explains the high values of the indicators. Even though a comparison to the previous literature is difficult, since we consider stocks (instead of flows) of faculties (instead of universities), the values seem to be in line with the literature. Using the number of publications in efficiency evaluations, Bolli et al. (2016) assume that European universities publish around 800 articles per year, while Gralka, Wohlrabe and Bornmann (2019) consider that German universities produces around 1000 articles per year. Evaluating German faculties of economics in particular Sternberg and Litzenberger (2005) show that the largest faculty, the faculty of economics at the University Mannheim, produces around 300 articles and receive around 500 citations over a time span of 10 years (1993-2002). The smaller, more average institutions, as the faculty of economics at the University Frankfurt, produces around 100 articles and receive around 100 citations in the same time period. It has to be noted, that the use of stocks instead of flows might bias the results or be even graded as unfair. RePEc unfortunately does not provide flow data. If one researcher changes its employer he or she takes his/her full publication history to the new institution. This favors the new institution and downgrades the previous one. However, economists or scientists in general often change institutions over the work life. It might be a realistic assumption that all institutions in our sample are affected in both ways: positively and negatively. Nevertheless, it is not possible to determine the net effect.

To account for the size of institutions, which influences their productivity (as shown by Worthington and Higgs 2011; Wolszczak-Derlacz and Parteka 2011 and Johnes and Johnes 2016), we normalize the indicators by the number of FTE. Without normalization the identified archetypoids would reflect mostly the size of the institutions. Large institutions produce more articles and potentially receive more citations and would therefore define the extreme values in the data. Hence, the second part of Table 2 shows the normalized indicators which are used in the analysis. Within an average institution of economics around 32 articles per capita are published, which contain around 322 pages in (refereed) journals and were downloaded around 172 times (again per capita). Per FTE the typical institution has received around 570 citations. It is thereby important to bear in mind again, that these numbers describe stock levels and that the per capita view concerns the number of current FTE.

\section{Results}

Given the seven indicators for each institution it is not obvious how many archetypoids are reasonable. The elbow criterion, is supposed to help to extract a clear cut-off point. In Fig. 1 we show the corresponding scree-plot of the RSS, which is used to determine the number of archetypoids to retain. Based on the scree-plot we perform an analysis with three potential archetypoids. However, since a potential flattening can also be detected for 4 and 5 archetypoids we discuss how the results change, if more archetypoids are considered, in the subsequent section five. 


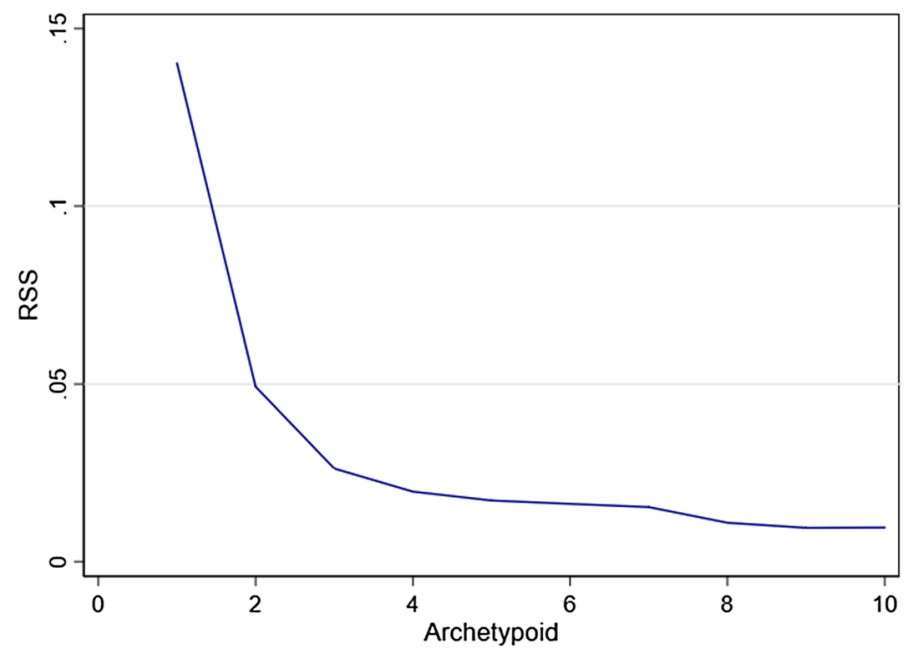

Fig. 1 RSS-plot

Figure 2 shows the bar-plots representing percentiles for three archetypoids. Bar-plots thereby serves as a different graphical representation of the convex hull. The height of each bar-plot denotes the share of the convex hull relative to the maximum in the category. Hence, the y-axis denotes the relevance of the indicator for the archetype. Table 3 provides additional context for the percentiles shown in Fig. 2. The table reports the archetypal value for each bibliometric indicator, when the reported percentiles are applied to the original (normalized) dataset. To give an example: while Archetypoid 1 published 14 works, Archetypoid 2 published 60 articles.

The three archetypoids can be interpreted as follows:

- Archetypoid 1 represent the low performer with a relatively low number of working papers and articles (14), citations (101) and downloads (81).

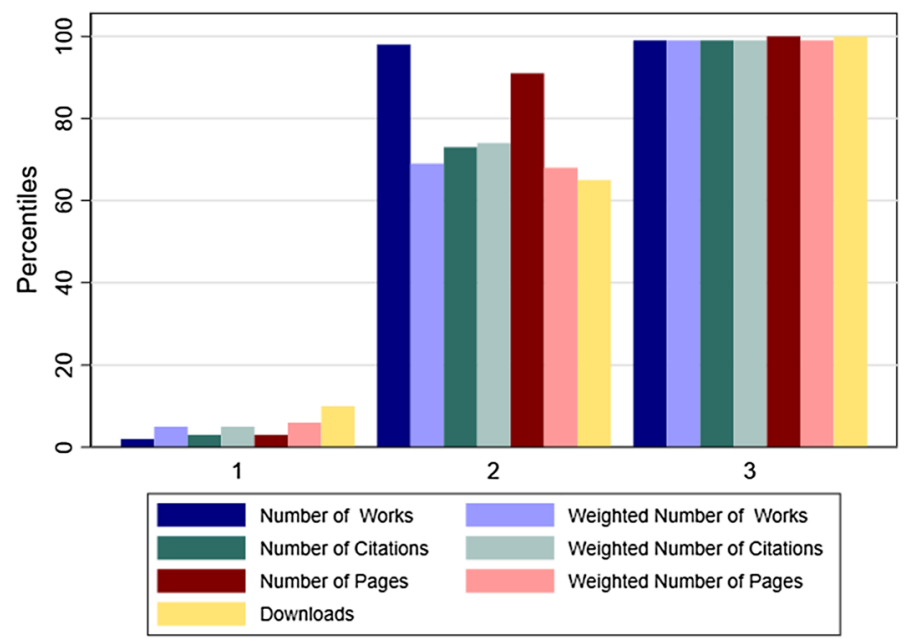

Fig. 2 Three archetypoids 
Table 3 Corresponding percentile values

\begin{tabular}{lllllllr}
\hline $\begin{array}{l}\text { Number } \\
\text { of Works }\end{array}$ & $\begin{array}{l}\text { Weighted } \\
\text { number of } \\
\text { works }\end{array}$ & $\begin{array}{l}\text { Number of } \\
\text { citations }\end{array}$ & $\begin{array}{l}\text { Weighted num- } \\
\text { ber of citations }\end{array}$ & $\begin{array}{l}\text { Number } \\
\text { of pages }\end{array}$ & $\begin{array}{l}\text { Weighted } \\
\text { number of } \\
\text { pages }\end{array}$ & Downloads \\
\hline 1 & 14 & 153 & 101 & 30 & 128 & 1240 & 81 \\
2 & 60 & 698 & 591 & 133 & 511 & 6297 & 165 \\
3 & 64 & 2616 & 2713 & 587 & 774 & 24,014 & 725 \\
\hline
\end{tabular}

- Archetypoid 3 denotes the excellent performer among the top-level institutions, given the other archetypoids. The institution performs well in all indicators, even if the indicators are quality weighted. Table 3 show that the corresponding values for each indicator are at least five times larger than the those for Archetypoid 1. In the case of citations, it is even more than 26 times larger.

- Archetypoid 2 denotes institutions between the previous two extremes, with a relatively high number of published work and pages. Nevertheless, both figures are smaller than for Archetypoid 3. In addition, compared to Archetypoid 3, the quality adjusted indicators are clearly lower as well as the citations and downloads. Still, they are larger than the figures of Archetypoid 1. The quantity dominates somewhat the quality of publications. Table 3 shows that the corresponding scores of Archetypoid 2 are substantially lower than those of Archetypoid 3 but are not as small as for Archetypoid 1.

Nevertheless, as we extracted the best economic institutions from RePEc, the terminus low performer for the first archetypoid must be interpreted cautiously. Compared to all institutions listed in RePEc every institution in our sample can be classified as top, nevertheless, compared among each other some perform worse than other ones.

Besides the aggregated analysis it is also possible to look at the relative share of each archetypoid for each institution. In practice, percentages of all three archetypoids are allocated to the institutions. This implies, that each institution is assigned three values, which add up to one. In Fig. 3 we show the box-plots for all percentage shares of the three identified archetypoids. It displays that most of the institutions in our data set are characterized by Archetype 2, the medium-performer, as it represents the largest relative shares. In comparison, the Archetype 1, the low performer, is less frequent. Of particular interest is the third archetypoid, the top-performer. As one would suspect, the majority of institutions in

Fig. 3 Barplots of archetypoid shares allocated to the institutions

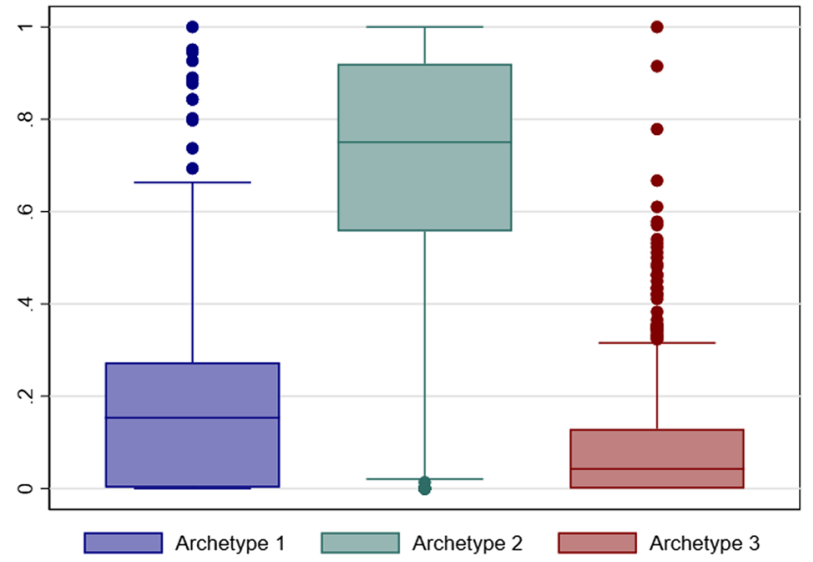


our sample have a low share of this archetypoid and only some - the true top-performerare assigned a large share of this archetypoid.

In addition to the more general view at the percentage shares of the three identified archetypoids, it also interesting to look at the association of single institutions to the three archetypoids. Figure 4 displays the allocation of each institutions to the identified types within a ternary plot. The edges of the triangle denote the shares and each circle denotes one institution. The diagram confirms that the Archetypoid 2 is the most frequent one. But is also shows that many institutions are a mixture of Archetypoid 1 and 2. The portion of Archetype 3 is often very small (see also Table 5).

In Table 4 we report the top five institutions for each archetypoid, i.e. institutions with the largest relative share for the respective archetypoid. The values for each institution of the sample can be found in the "Appendix" in Table 5. A value of 1.000 denotes that the respective institution represents the identified archetypoid perfectly. By assumption, this is the case for at least one institution for all three archetypoids. The faculty of economics at the Massachusetts Institute of Technology (MIT) represents the Archetypoid 3, the top-performer. In contrast, the Department of Agricultural and Resource Economics at the University of California-Davis represents the Archetypoid 1, the low-performer. More than one institution, to be precise 34 institutions, represent the medium-performer, which is plausible since the type is most common among the three archetypoids. Nevertheless, in most cases, institutions are a mixture of the three different archetypoids.

\section{Sensitivity Analysis}

Since the scree-plot of Fig. 1 showed that the number of archetypoids is arbitrary, we show what happens if we consider 4 or 5 archetypoids instead of 3 . This addition not only shows the robustness of the results, but also provides some additional insights.

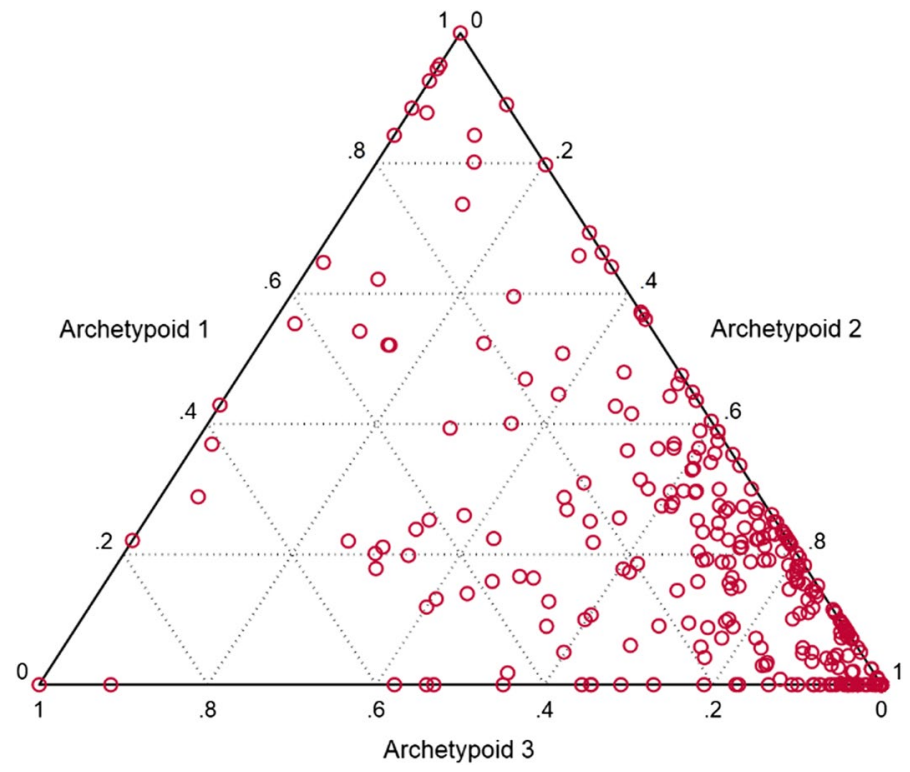

Fig. 4 Ternary plot of the three archetypoids 
Table 4 Top five archetypoid shares

\begin{tabular}{llll}
\hline Archetypoid & 1 & 2 & 3 \\
\hline Department of Agricultural and Resource Economics, Univ. of California-Davis & 1.000 & 0.000 & 0.000 \\
Sciences économiques, Sciences Po & 0.951 & 0.000 & 0.049 \\
Econometrisch Instituut, Erasmus Universiteit Rotterdam & 0.945 & 0.000 & 0.055 \\
Dyson School of Applied Economics and Management, Cornell University & 0.927 & 0.000 & 0.074 \\
KOF Swiss Economic Institute, Eidgenössische Techn. Hochschule Zürich (ETHZ) & 0.890 & 0.110 & 0.000 \\
Organisation de Coopération et de Développement Économiques (OCDE) & 0.000 & 1.000 & 0.000 \\
Banca dItalia & 0.000 & 1.000 & 0.000 \\
National Research University Higher School of Economics & 0.000 & 1.000 & 0.000 \\
Banque de France & 0.000 & 1.000 & 0.000 \\
Banco de España & 0.000 & 1.000 & 0.000 \\
Economics Department, Massachusetts Institute of Technology (MIT) & 0.000 & 0.000 & 1.000 \\
Department of Economics, Harvard University & 0.000 & 0.085 & 0.915 \\
Department of Economics, University of California-Berkeley & 0.221 & 0.000 & 0.779 \\
National Bureau of Economic Research (NBER) & 0.288 & 0.045 & 0.667 \\
Finance and Economics Department, Graduate School of Business, Columbia Univ. & 0.369 & 0.020 & 0.610
\end{tabular}

Figure 5 displays that the already classified archetypoids 1 to 3 seem to remain, even if more classes are allowed. Moreover, we see, that the inclusion of a fourth archetypoid, allows to distinguish between two medium-performers: the ones which appear agreeable when the absolute numbers are assessed (Archetypoid 1) and the ones which hold their performance also when the output is weighted (Archetypoid 2). Similarly, the inclusion of fifth archetypoid allows to distinguish between the true low-performer (Archetypoid 3) and faculties that have a larger outreach, indicated in particular by the number of downloads (Archetypoid 5).

\section{Conclusions}

In this paper we introduced archetypoid analysis to the evaluation of institutions and faculties of economics. We argue that the method offers a suitable and straight-forward way to classify institutions based on observed data. The analysis allows to extract typical characteristics (archetypoids) within a multivariate data set. We evaluate 298 economic institutions obtained from the RePEc database. We have seven bibliometric scores for each institution, spanning over various measures of (quality-weighted) number of published work, citations and access statistics.

We identified three main archetypoids, which are characterized as top- and low-performer and the institutions between these two extremes. The results are robust for the allowance of additional archetypoids. We must mention two caveats for our analysis. Firstly, we employ stock levels for the classification. While this is a typical approach for the creating of rankings, it has obvious disadvantages. For instance, institutions profit from the whole publication record of their scientists, even though some of the work could have been done at a previous institution. Secondly, our set of economic institutions and faculties are quite heterogeneous. We focus on research related indicators and leave out aspects as 

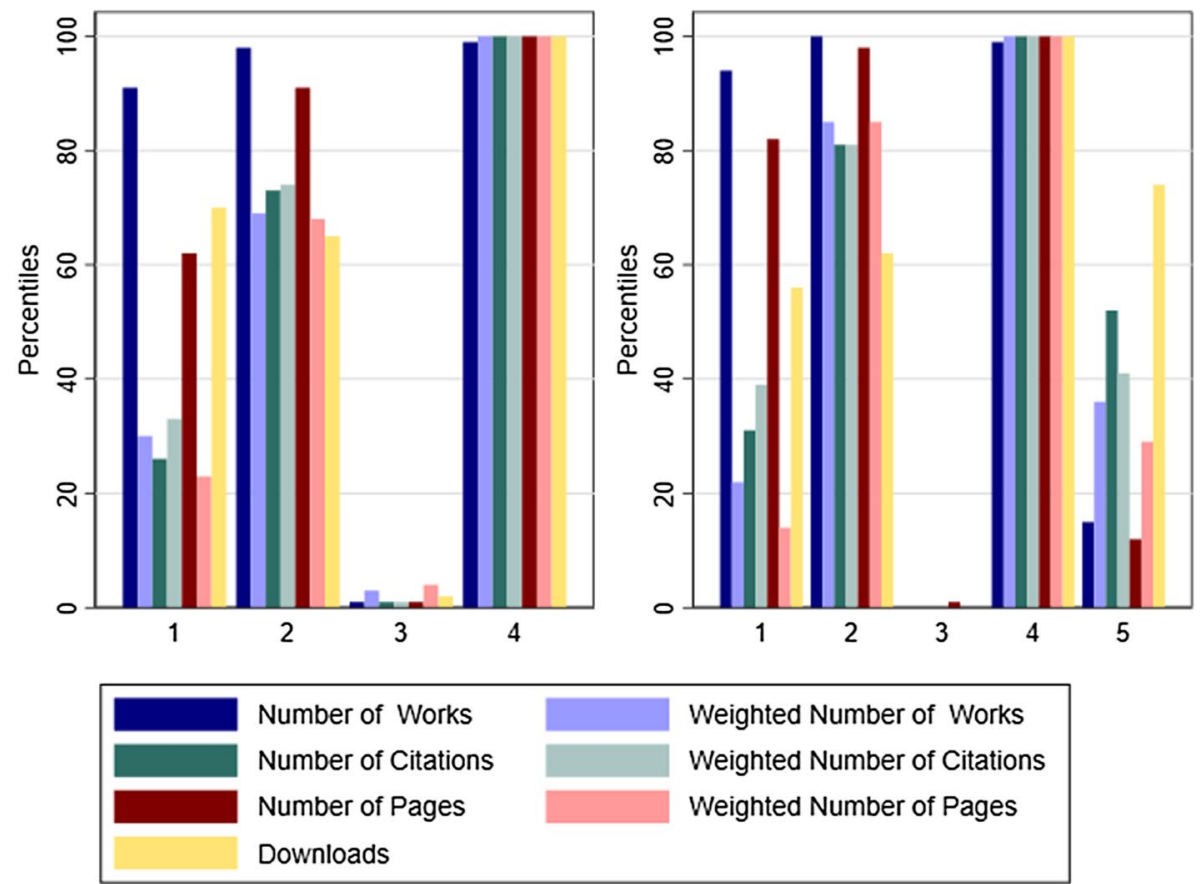

Fig. 5 Barplots representing four and five archetypoids

teaching which might influence our analysis. Thus, future research should include further characteristics of science, as teaching and the acquisition of grants, among others.

Acknowledgements Open Access funding provided by Projekt DEAL.

Funding This research received no external funding.

\section{Compliance with ethical standards}

Conflicts of interest The authors declare no conflict of interest.

Open Access This article is licensed under a Creative Commons Attribution 4.0 International License, which permits use, sharing, adaptation, distribution and reproduction in any medium or format, as long as you give appropriate credit to the original author(s) and the source, provide a link to the Creative Commons licence, and indicate if changes were made. The images or other third party material in this article are included in the article's Creative Commons licence, unless indicated otherwise in a credit line to the material. If material is not included in the article's Creative Commons licence and your intended use is not permitted by statutory regulation or exceeds the permitted use, you will need to obtain permission directly from the copyright holder. To view a copy of this licence, visit http://creativecommons.org/licenses/by/4.0/.

\section{Appendix}

See Table 5 . 
Table 5 Considered institutions and their shares in each archetypoid

\begin{tabular}{|c|c|c|c|}
\hline \multirow[t]{2}{*}{ Institution } & \multicolumn{3}{|c|}{ Archetypoid Shares } \\
\hline & 1 & 2 & 3 \\
\hline Abteilung für Volkswirtschaftslehre, Universität Mannheim & 0.000 & 0.960 & 0.040 \\
\hline Adam Smith Business School, Univ. of Glasgow & 0.119 & 0.859 & 0.022 \\
\hline $\begin{array}{l}\text { Anderson Graduate School of Management, Univ. of California-Los Angeles } \\
\text { (UCLA) }\end{array}$ & 0.164 & 0.505 & 0.331 \\
\hline Andrew Young School of Policy Studies, Georgia State Univ. & 0.173 & 0.813 & 0.014 \\
\hline Argyros School of Business and Econ., Chapman Univ. & 0.275 & 0.670 & 0.055 \\
\hline Athens Univ. of Econ. and Business (AUEB) & 0.087 & 0.913 & 0.000 \\
\hline Banca dItalia & 0.000 & 1.000 & 0.000 \\
\hline Banco de España & 0.000 & 1.000 & 0.000 \\
\hline Bank for International Settlements (BIS) & 0.072 & 0.775 & 0.154 \\
\hline Bank of Canada & 0.000 & 1.000 & 0.000 \\
\hline Bank of England & 0.000 & 1.000 & 0.000 \\
\hline Banque de France & 0.000 & 1.000 & 0.000 \\
\hline Barcelona Graduate School of Econ. (Barcelona GSE) & 0.057 & 0.878 & 0.065 \\
\hline Booth School of Business, Univ. of Chicago & 0.000 & 0.422 & 0.578 \\
\hline Brookings Institution & 0.521 & 0.156 & 0.323 \\
\hline Business School, Deakin Univ. & 0.110 & 0.890 & 0.000 \\
\hline Business School, Imperial College & 0.151 & 0.755 & 0.094 \\
\hline Business School, Univ. of Exeter & 0.000 & 1.000 & 0.000 \\
\hline Business School, Univ. of Technology Sydney & 0.000 & 1.000 & 0.000 \\
\hline Cardiff Business School, Cardiff Univ. & 0.098 & 0.902 & 0.000 \\
\hline Carol Martin Gatton College of Business and Econ., Univ. of Kentucky & 0.109 & 0.848 & 0.043 \\
\hline Cass Business School, City Univ. & 0.148 & 0.748 & 0.105 \\
\hline Census Bureau, Department of Commerce, Government of the United States & 0.000 & 0.983 & 0.017 \\
\hline $\begin{array}{l}\text { Center for Operations Research and Econometrics (CORE), Univ. Catholique } \\
\text { Louvain }\end{array}$ & 0.843 & 0.095 & 0.062 \\
\hline Central Univ. of Finance and Econ. (CUFE) & 0.000 & 1.000 & 0.000 \\
\hline Centre de Recherche en Économie et Statistique (CREST) & 0.266 & 0.681 & 0.052 \\
\hline Centre dÉconomie de la Sorbonne, Univ. Paris 1 (Panthéon-Sorbonne) & 0.000 & 1.000 & 0.000 \\
\hline Centre for Economic Performance (CEP), London School of Econ. (LSE) & 0.198 & 0.339 & 0.462 \\
\hline Centre for Economic Policy Research (CEPR) & 0.554 & 0.027 & 0.419 \\
\hline Centro Studi di Economia e Finanza (CSEF) & 0.000 & 0.927 & 0.073 \\
\hline Centrum voor Economische Studiën, KU Leuven & 0.330 & 0.610 & 0.060 \\
\hline CESifo & 0.878 & 0.021 & 0.101 \\
\hline Charles H. Dyson School of Applied Econ. and Management, Cornell Univ. & 0.927 & 0.000 & 0.074 \\
\hline College of Business and Behavioral Science, Clemson Univ. & 0.026 & 0.936 & 0.038 \\
\hline College of Business and Econ., Australian National Univ. & 0.223 & 0.740 & 0.037 \\
\hline Copenhagen Business School & 0.024 & 0.976 & 0.000 \\
\hline Crawford School of Public Policy, Australian National Univ. & 0.389 & 0.611 & 0.000 \\
\hline de Nederlandsche Bank & 0.000 & 1.000 & 0.000 \\
\hline Departament dEconomia i Empresa, Univ. Pompeu Fabra & 0.000 & 0.920 & 0.080 \\
\hline Departament dEconomia i Història Econòmica, Univ. Autònoma de Barcelona & 0.136 & 0.855 & 0.009 \\
\hline $\begin{array}{l}\text { Departamento de Economía, Facultad de Economía y Negocios, Universidad de } \\
\text { Chile }\end{array}$ & 0.300 & 0.695 & 0.004 \\
\hline
\end{tabular}


Table 5 (continued)

Institution Archetypoid Shares

$1 \quad 2 \quad 3$

Departamento de Economía, Universidad Carlos III de Madrid

$\begin{array}{lll}0.111 & 0.858 & 0.032\end{array}$

Département Sciences Sociales, Institut National de la Recherche Agronomique

$\begin{array}{lll}0.078 & 0.922 & 0.000\end{array}$

Department of Agricultural and Resource Econ., Univ. of California-Berkeley

$\begin{array}{lll}0.843 & 0.000 & 0.157\end{array}$

Department of Agricultural and Resource Econ., Univ. of California-Davis

$\begin{array}{lll}1.000 & 0.000 & 0.000\end{array}$

Department of Agricultural Econ., Purdue Univ.

Department of Agricultural, Food and Resource Econ., Michigan State Univ.

$\begin{array}{lll}0.568 & 0.432 & 0.000\end{array}$

Department of Applied Econ., Univ. of Minnesota-St. Paul

Department of Commerce, Government of the United States

Department of Econometrics and Business Statistics, Monash Univ.

$\begin{array}{lll}0.561 & 0.439 & 0.000\end{array}$

$\begin{array}{lll}0.388 & 0.612 & 0.000\end{array}$

$\begin{array}{lll}0.000 & 0.997 & 0.003\end{array}$

$\begin{array}{lll}0.462 & 0.527 & 0.011\end{array}$

Department of Econ. and Related Studies, Univ. of York

Department of Econ., Adam Smith Business School, Univ. of Glasgow

$\begin{array}{lll}0.157 & 0.820 & 0.022\end{array}$

Department of Econ., Andrew Y. School of Policy Studies, Georgia State Univ.

$\begin{array}{lll}0.191 & 0.771 & 0.038\end{array}$

Department of Econ., Boston College

$\begin{array}{lll}0.183 & 0.798 & 0.019\end{array}$

$\begin{array}{lll}0.095 & 0.724 & 0.182\end{array}$

Department of Econ., Boston Univ.

Department of Econ., Business School, Deakin Univ.

Department of Econ., Carleton Univ.

$\begin{array}{lll}0.107 & 0.602 & 0.291\end{array}$

$\begin{array}{lll}0.261 & 0.739 & 0.000\end{array}$

$\begin{array}{lll}0.094 & 0.906 & 0.000\end{array}$

Department of Econ., Cornell Univ.

$\begin{array}{lll}0.622 & 0.091 & 0.287\end{array}$

Department of Econ., Duke Univ.

Department of Econ., Faculty of Business and Econ., Univ. of Melbourne

$\begin{array}{lll}0.186 & 0.617 & 0.197\end{array}$

Department of Econ., George Washington Univ.

$\begin{array}{lll}0.218 & 0.782 & 0.000\end{array}$

$\begin{array}{lll}0.000 & 0.963 & 0.037\end{array}$

Department of Econ., Harvard Univ.

$\begin{array}{lll}0.000 & 0.085 & 0.915\end{array}$

Department of Econ., Hebrew Univ. of Jerusalem

$0.101 \quad 0.768 \quad 0.131$

Department of Econ., Iowa State Univ.

Department of Econ., Johns Hopkins Univ.

Department of Econ., Management School, Lancaster Univ.

$\begin{array}{lll}0.693 & 0.307 & 0.000\end{array}$

$\begin{array}{lll}0.542 & 0.109 & 0.348\end{array}$

$\begin{array}{lll}0.115 & 0.885 & 0.000\end{array}$

Department of Econ., Maxwell School, Syracuse Univ.

Department of Econ., McGill Univ.

Department of Econ., McMaster Univ.

Department of Econ., Monash Business School, Monash Univ.

$\begin{array}{lll}0.508 & 0.367 & 0.124\end{array}$

$\begin{array}{lll}0.370 & 0.569 & 0.061\end{array}$

$\begin{array}{lll}0.182 & 0.811 & 0.007\end{array}$

$\begin{array}{lll}0.349 & 0.603 & 0.048\end{array}$

Department of Econ., National Univ. of Singapore (NUS)

Department of Econ., New York Univ. (NYU)

Department of Econ., Northwestern Univ.

$\begin{array}{lll}0.045 & 0.924 & 0.030\end{array}$

$\begin{array}{lll}0.018 & 0.547 & 0.435\end{array}$

$\begin{array}{lll}0.000 & 0.655 & 0.345\end{array}$

Department of Econ., Ohio State Univ.

$0.204 \quad 0.680 \quad 0.116$

Department of Econ., Oxford Univ.

Department of Econ., Pennsylvania State Univ.

Department of Econ., Princeton Univ.

Department of Econ., Rutgers Univ.-New Brunswick

$\begin{array}{lll}0.071 & 0.815 & 0.113\end{array}$

$\begin{array}{lll}0.173 & 0.614 & 0.213\end{array}$

$\begin{array}{lll}0.000 & 0.468 & 0.532\end{array}$

$0.428 \quad 0.470 \quad 0.102$

$\begin{array}{lll}0.221 & 0.257 & 0.523\end{array}$

Department of Econ., School of Arts and Sciences, Columbia Univ.

$\begin{array}{lll}0.287 & 0.480 & 0.233\end{array}$

Department of Econ., Sciences économiques, Sciences Po

$\begin{array}{lll}0.211 & 0.728 & 0.061\end{array}$

Department of Econ., Simon Fraser Univ.

$0.119 \quad 0.400 \quad 0.480$

Department of Econ., Sussex Business School, Univ. of Sussex

$\begin{array}{lll}0.155 & 0.830 & 0.015\end{array}$

Department of Econ., Texas A\&M Univ.

$0.297 \quad 0.616 \quad 0.086$ 
Table 5 (continued)

Institution Archetypoid Shares

然

Department of Econ., Tufts Univ.

$1 \quad 2 \quad 3$

Department of Econ., Univ. College London (UCL)

$\begin{array}{lll}0.231 & 0.690 & 0.079\end{array}$

Department of Econ., Univ. of Alberta

Department of Econ., Univ. of Birmingham

Department of Econ., Univ. of Calgary

Department of Econ., Univ. of California-Berkeley

$\begin{array}{lll}0.060 & 0.672 & 0.268\end{array}$

$\begin{array}{lll}0.000 & 1.000 & 0.000\end{array}$

$\begin{array}{lll}0.213 & 0.755 & 0.032\end{array}$

$\begin{array}{lll}0.162 & 0.818 & 0.020\end{array}$

Department of Econ., Univ. of California-Irvine

Department of Econ., Univ. of California-Los Angeles (UCLA)

$\begin{array}{lll}0.221 & 0.000 & 0.779\end{array}$

$\begin{array}{lll}0.315 & 0.556 & 0.129\end{array}$

Department of Econ., Univ. of California-Riverside

$\begin{array}{lll}0.090 & 0.691 & 0.219\end{array}$

$\begin{array}{lll}0.223 & 0.742 & 0.034\end{array}$

Department of Econ., Univ. of California-San Diego (UCSD)

$\begin{array}{lll}0.000 & 0.644 & 0.356\end{array}$

Department of Econ., Univ. of California-Santa Barbara (UCSB)

$\begin{array}{lll}0.401 & 0.360 & 0.239\end{array}$

Department of Econ., Univ. of Chicago

$\begin{array}{lll}0.000 & 0.551 & 0.449\end{array}$

Department of Econ., Univ. of Colorado

$\begin{array}{lll}0.156 & 0.741 & 0.103\end{array}$

Department of Econ., Univ. of Connecticut

$\begin{array}{lll}0.215 & 0.785 & 0.000\end{array}$

Department of Econ., Univ. of Maryland

$\begin{array}{lll}0.178 & 0.604 & 0.218\end{array}$

Department of Econ., Univ. of Minnesota

$\begin{array}{lll}0.000 & 0.830 & 0.170\end{array}$

Department of Econ., Univ. of Notre Dame

$\begin{array}{lll}0.000 & 0.900 & 0.100\end{array}$

Department of Econ., Univ. of Oregon

$\begin{array}{lll}0.234 & 0.671 & 0.095\end{array}$

Department of Econ., Univ. of Pennsylvania

$\begin{array}{lll}0.239 & 0.328 & 0.433\end{array}$

Department of Econ., Univ. of Pittsburgh

$\begin{array}{lll}0.000 & 0.965 & 0.035\end{array}$

Department of Econ., Univ. of Sheffield

$\begin{array}{lll}0.070 & 0.930 & 0.000\end{array}$

Department of Econ., Univ. of Southern California

$\begin{array}{lll}0.269 & 0.492 & 0.239\end{array}$

Department of Econ., Univ. of Texas-Austin

Department of Econ., Univ. of Toronto

$\begin{array}{lll}0.000 & 0.919 & 0.081\end{array}$

Department of Econ., Univ. of Virginia

$\begin{array}{lll}0.097 & 0.766 & 0.136\end{array}$

$\begin{array}{lll}0.088 & 0.750 & 0.162\end{array}$

Department of Econ., Univ. of Warwick

$\begin{array}{lll}0.188 & 0.717 & 0.095\end{array}$

Department of Econ., Univ. of Western Ontario

Department of Econ., Vanderbilt Univ.

$\begin{array}{lll}0.252 & 0.655 & 0.092\end{array}$

$\begin{array}{lll}0.737 & 0.134 & 0.129\end{array}$

Department of Econ., W.P. Carey School of Business, Arizona State Univ.

$\begin{array}{lll}0.191 & 0.692 & 0.117\end{array}$

Department of Econ., Waikato Management School, Univ. of Waikato

$\begin{array}{lll}0.641 & 0.359 & 0.000\end{array}$

Department of Econ., Washington Univ. in St. Louis

Department of Geography and Environment, London School of Econ. (LSE)

$\begin{array}{lll}0.256 & 0.561 & 0.183\end{array}$

$\begin{array}{lll}0.524 & 0.266 & 0.210\end{array}$

Department of Management, Technology and Econ., ETHZ

$\begin{array}{lll}0.475 & 0.525 & 0.000\end{array}$

Department Volkswirtschaftlehre, Universität Bern

$\begin{array}{lll}0.189 & 0.750 & 0.061\end{array}$

Deutsche Bundesbank

$\begin{array}{lll}0.000 & 1.000 & 0.000\end{array}$

Dipartimenti e Istituti di Scienze Economiche, Università Cattolica del Sacro Cuore

$\begin{array}{lll}0.082 & 0.918 & 0.000\end{array}$

Dipartimento di Economia “Ettore Bocconi”, Università Commerciale Luigi Boc-

$\begin{array}{lll}0.158 & 0.703 & 0.139\end{array}$ coni

Dipartimento di Economia e Finanza, Libera Università Internazionale (LUISS)

$\begin{array}{lll}0.231 & 0.758 & 0.011\end{array}$

Dipartimento di Economia e Finanza, Università Cattolica del Sacro Cuore

$\begin{array}{lll}0.236 & 0.764 & 0.000\end{array}$

Dipartimento di Economia e Finanza, Università degli Studi di Roma "Tor Vergata"

$\begin{array}{lll}0.264 & 0.719 & 0.017\end{array}$

Dipartimento di Economia e Statistica "Cognetti de Martiis", Università di Torino

$\begin{array}{lll}0.337 & 0.663 & 0.000\end{array}$

Dipartimento di Economia, Management e Metodi Quantitativi, Università di

$0.000 \quad 1.000 \quad 0.000$ Milano 
Table 5 (continued)

\begin{tabular}{|c|c|c|c|}
\hline \multirow[t]{2}{*}{ Institution } & \multicolumn{3}{|c|}{ Archetypoid Shares } \\
\hline & 1 & 2 & 3 \\
\hline Dipartimento di Economia, Università Ca Foscari Venezia & 0.011 & 0.989 & 0.000 \\
\hline $\begin{array}{l}\text { Dipartimento di Scienze Economiche "Marco Fanno", Università degli Studi di } \\
\text { Padova }\end{array}$ & 0.081 & 0.919 & 0.000 \\
\hline $\begin{array}{l}\text { Dipartimento di Scienze Economiche, Alma Mater Studiorum-Università di } \\
\text { Bologna }\end{array}$ & 0.221 & 0.779 & 0.000 \\
\hline DIW Berlin (Deutsches Institut für Wirtschaftsforschung) & 0.798 & 0.202 & 0.000 \\
\hline Düsseldorf Institute for Competition Econ., Heinriche-Heine-Univ. Düsseldorf & 0.000 & 1.000 & 0.000 \\
\hline École dÉconomie dAix-Marseille, Aix-Marseille Univ. & 0.152 & 0.848 & 0.000 \\
\hline École des Sciences Économiques de Louvain, Univ. Catholique de Louvain & 0.443 & 0.527 & 0.030 \\
\hline Econometrisch Instituut, Erasmus Universiteit Rotterdam & 0.945 & 0.000 & 0.055 \\
\hline Economic Research Department, Federal Reserve Bank of Atlanta & 0.416 & 0.495 & 0.089 \\
\hline Economic Research Department, Federal Reserve Bank of Chicago & 0.048 & 0.882 & 0.070 \\
\hline Economic Research Department, Federal Reserve Bank of Dallas & 0.341 & 0.626 & 0.032 \\
\hline Economic Research Service,, Government of the United States & 0.112 & 0.888 & 0.000 \\
\hline Economic Research, Federal Reserve Bank of San Francisco & 0.469 & 0.343 & 0.188 \\
\hline Econ. Department, Brown Univ. & 0.000 & 0.655 & 0.345 \\
\hline Econ. Department, Dartmouth College & 0.253 & 0.337 & 0.411 \\
\hline Econ. Department, Georgetown Univ. & 0.310 & 0.492 & 0.199 \\
\hline Econ. Department, London School of Econ. (LSE) & 0.000 & 0.691 & 0.309 \\
\hline Econ. Department, Massachusetts Institute of Technology (MIT) & 0.000 & 0.000 & 1.000 \\
\hline Econ. Department, Michigan State Univ. & 0.058 & 0.756 & 0.186 \\
\hline Econ. Department, Organisation de Coopération et de Développement Économiques & 0.072 & 0.917 & 0.012 \\
\hline Econ. Department, Queens Univ. & 0.274 & 0.613 & 0.113 \\
\hline Econ. Department, Stern School of Business, New York Univ. (NYU) & 0.260 & 0.375 & 0.365 \\
\hline Econ. Department, Univ. of California-Davis & 0.218 & 0.548 & 0.233 \\
\hline Econ. Department, Univ. of California-Santa Cruz (UCSC) & 0.596 & 0.265 & 0.139 \\
\hline Econ. Department, Univ. of Essex & 0.041 & 0.914 & 0.045 \\
\hline Econ. Department, Univ. of Michigan & 0.042 & 0.769 & 0.189 \\
\hline Econ. Department, Univ. of Missouri & 0.296 & 0.601 & 0.103 \\
\hline Econ. Department, Univ. of Strathclyde & 0.273 & 0.699 & 0.028 \\
\hline Econ. Department, Univ. of Wisconsin-Madison & 0.166 & 0.487 & 0.346 \\
\hline Econ. Department, Yale Univ. & 0.211 & 0.302 & 0.486 \\
\hline Econ. Discipline Group, Business School, Univ. of Technology Sydney & 0.000 & 1.000 & 0.000 \\
\hline Econ. Research, World Bank Group & 0.301 & 0.573 & 0.127 \\
\hline Econ., New York Univ. Abu Dhabi & 0.188 & 0.725 & 0.087 \\
\hline Eitan Berglas School of Econ., Tel Aviv Univ. & 0.521 & 0.153 & 0.325 \\
\hline Ekonomihögskolan, Lunds Universitet & 0.000 & 1.000 & 0.000 \\
\hline European Central Bank & 0.000 & 0.961 & 0.039 \\
\hline $\begin{array}{l}\text { European Centre for Advanced Research in Econ. and Stat., Univ. Libre de Brux- } \\
\text { elles }\end{array}$ & 0.300 & 0.657 & 0.043 \\
\hline Fachbereich Wirtschaftswissenschaft, Freie Universität Berlin & 0.131 & 0.847 & 0.022 \\
\hline Fachbereich Wirtschaftswissenschaft, Goethe Universität Frankfurt am Main & 0.045 & 0.938 & 0.017 \\
\hline Facoltà di Economia "Giorgio Fuà", Università Politecnica delle Marche & 0.000 & 1.000 & 0.000 \\
\hline Facoltà di Economia, Università degli Studi di Roma "Tor Vergata" & 0.010 & 0.990 & 0.000 \\
\hline
\end{tabular}


Table 5 (continued)

Institution

Archetypoid Shares

$\begin{array}{lll}1 & 2 & 3\end{array}$

Facultad de Economía y Empresa, Universidad del País Vasco-E. H. Unibertsitatea

$\begin{array}{lll}0.000 & 1.000 & 0.000\end{array}$

Facultad de Economía y Negocios, Universidad de Chile

$\begin{array}{lll}0.183 & 0.817 & 0.000\end{array}$

Facultad de Economía, Universidad de València

Facultat dEconomia i Empresa, Univ. de Barcelona

$\begin{array}{lll}0.084 & 0.916 & 0.000\end{array}$

Faculté de droit, déconomie et de finance, Univ. du Luxembourg

$\begin{array}{lll}0.000 & 1.000 & 0.000\end{array}$

$\begin{array}{lll}0.057 & 0.943 & 0.000\end{array}$

Faculté des Hautes Études Commerciales (HEC), Univ. de Lausanne

$\begin{array}{lll}0.000 & 0.959 & 0.041\end{array}$

Faculteit der Economische Wetenschappen, Erasmus Universiteit Rotterdam

$\begin{array}{lll}0.232 & 0.753 & 0.016\end{array}$

Faculteit Economie en Bedrijfskunde, Rijksuniversiteit Groningen

Faculteit Economie en Bedrijfskunde, Universiteit Gent

$\begin{array}{lll}0.332 & 0.611 & 0.058\end{array}$

$\begin{array}{lll}0.000 & 1.000 & 0.000\end{array}$

Faculteit Economie en Bedrijfskunde, Universiteit van Amsterdam

$\begin{array}{lll}0.191 & 0.765 & 0.044\end{array}$

Faculteit Economie en Bedrijfswetenschappen, KU Leuven

Faculty of Business and Econ., Univ. of Melbourne

$\begin{array}{lll}0.205 & 0.780 & 0.015\end{array}$

$\begin{array}{lll}0.226 & 0.774 & 0.000\end{array}$

Faculty of Econ., Univ. of Cambridge

Faculty of Econ., Univ. of Tokyo

Fakultät für Wirtschaftswissenschaften, Universität Wien

$\begin{array}{lll}0.274 & 0.602 & 0.124\end{array}$

$\begin{array}{llll}0.363 & 0.602 & 0.035\end{array}$

$\begin{array}{lll}0.142 & 0.851 & 0.007\end{array}$

Federal Reserve Bank of Atlanta

$\begin{array}{lll}0.359 & 0.519 & 0.122\end{array}$

Federal Reserve Bank of Boston

$\begin{array}{lll}0.021 & 0.956 & 0.023\end{array}$

Federal Reserve Bank of Chicago

$\begin{array}{lll}0.034 & 0.847 & 0.119\end{array}$

Federal Reserve Bank of Cleveland

$\begin{array}{llll}0.169 & 0.811 & 0.021\end{array}$

Federal Reserve Bank of Dallas

$\begin{array}{lll}0.222 & 0.707 & 0.071\end{array}$

Federal Reserve Bank of Minneapolis

$\begin{array}{lll}0.128 & 0.541 & 0.331\end{array}$

Federal Reserve Bank of New York

Federal Reserve Bank of Philadelphia

$\begin{array}{lll}0.000 & 0.866 & 0.134\end{array}$

$\begin{array}{lll}0.050 & 0.892 & 0.058\end{array}$

Federal Reserve Bank of Richmond

$\begin{array}{lll}0.297 & 0.632 & 0.071\end{array}$

Federal Reserve Bank of San Francisco

$\begin{array}{lll}0.446 & 0.394 & 0.161\end{array}$

Federal Reserve Bank of St. Louis

Federal Reserve Board (Board of Governors of the Federal Reserve System)

Finance and Econ. Department, Graduate School of Business, Columbia Univ.

$\begin{array}{lll}0.802 & 0.115 & 0.083\end{array}$

$\begin{array}{lll}0.000 & 0.966 & 0.034\end{array}$

$\begin{array}{lll}0.369 & 0.020 & 0.610\end{array}$

Graduate School of Business, Columbia Univ.

Graduate School of Business, Stanford Univ.

Groupe dAnalyse et de Théorie Économique Lyon St-Étienne, Univ. de Lyon

$\begin{array}{lll}0.140 & 0.438 & 0.422\end{array}$

$\begin{array}{lll}0.000 & 0.460 & 0.540\end{array}$

$\begin{array}{lll}0.050 & 0.950 & 0.000\end{array}$

Groupement de Recherche en Économie Quantitative, Aix-Marseille Univ.

$\begin{array}{lll}0.249 & 0.751 & 0.000\end{array}$

Handelshögskolan i Stockholm

Handelshögskolan, Göteborgs Universitet

Harris School of Public Policy, Univ. of Chicago

Harvard Business School, Harvard Univ.

HEC Montréal (École des Hautes Études Commerciales)

$\begin{array}{lll}0.029 & 0.844 & 0.127\end{array}$

$\begin{array}{lll}0.081 & 0.911 & 0.008\end{array}$

$\begin{array}{lll}0.090 & 0.557 & 0.353\end{array}$

$\begin{array}{lll}0.000 & 0.729 & 0.271\end{array}$

$\begin{array}{lll}0.355 & 0.625 & 0.021\end{array}$

School of Econ. and Management, Universiteit van Tilburg

$\begin{array}{lll}0.390 & 0.590 & 0.021\end{array}$

ifo Institut-Leibniz-Institut für Wirtschaftsforschung an der Universität München

$\begin{array}{lll}0.572 & 0.428 & 0.000\end{array}$ e.V.

Innocenzo Gasparini Institute for Econ. Research, Università Commerciale L. Boc-

$\begin{array}{lll}0.224 & 0.427 & 0.348\end{array}$ coni

Institut dÉconomie Industrielle (IDEI), Toulouse School of Econ. (TSE)

$\begin{array}{lll}0.429 & 0.000 & 0.571\end{array}$

Institut for Økonomi, Aarhus Universitet

$\begin{array}{lll}0.147 & 0.817 & 0.036\end{array}$ 
Table 5 (continued)

Institution Archetypoid Shares

$1 \quad 2 \quad 3$

Institut für Volkswirtschaftslehre, Johannes-Kepler-Universität Linz

$\begin{array}{lll}0.144 & 0.845 & 0.011\end{array}$

Institut für Volkswirtschaftslehre, Universität Zürich

$\begin{array}{lll}0.000 & 0.971 & 0.029\end{array}$

Institut für Weltwirtschaft (IfW)

Institute of Labor Econ. (IZA)

Institutet för Näringslivsforskning (IFN)

Institutt for samfunnsøkonomi, Norges Handelshøyskole (NHH)

$\begin{array}{lll}0.663 & 0.337 & 0.000\end{array}$

$\begin{array}{lll}0.362 & 0.554 & 0.084\end{array}$

$\begin{array}{lll}0.002 & 0.951 & 0.048\end{array}$

$\begin{array}{lll}0.036 & 0.899 & 0.065\end{array}$

Inter-American Development Bank

$\begin{array}{lll}0.000 & 1.000 & 0.000\end{array}$

International Bank for Reconstruction \& Development (IBRD), World Bank Group

$\begin{array}{lll}0.000 & 1.000 & 0.000\end{array}$

International Econ. Section, The Graduate Institute of Intern. and Development

$\begin{array}{lll}0.000 & 0.956 & 0.044\end{array}$ Studies

International Food Policy Research Institute (IFPRI)

$\begin{array}{lll}0.201 & 0.799 & 0.000\end{array}$

International Monetary Fund (IMF)

Judge Business School, Univ. of Cambridge

Kellogg Graduate School of Management, Northwestern Univ.

$\begin{array}{lll}0.000 & 0.981 & 0.019\end{array}$

$\begin{array}{lll}0.101 & 0.844 & 0.055\end{array}$

$\begin{array}{lll}0.000 & 0.789 & 0.211\end{array}$

Kennedy School of Government, Harvard Univ.

KOF Swiss Economic Institute, Eidgenössische Technische Hochschule Zürich

$\begin{array}{lll}0.132 & 0.405 & 0.463\end{array}$

$\begin{array}{lll}0.890 & 0.110 & 0.000\end{array}$

Laboratory of Econ. and Management (LEM), Scuola Superiore SantAnna

Leibniz-Zentrum für Europäische Wirtschaftsforschung (ZEW)

Lille Économie et Management (LEM)

$\begin{array}{lll}0.279 & 0.613 & 0.108\end{array}$

$\begin{array}{lll}0.000 & 1.000 & 0.000\end{array}$

$\begin{array}{lll}0.000 & 1.000 & 0.000\end{array}$

London School of Econ. (LSE)

$\begin{array}{lll}0.145 & 0.685 & 0.170\end{array}$

Management School, Lancaster Univ.

$\begin{array}{lll}0.195 & 0.805 & 0.000\end{array}$

Melbourne Institute of Applied Economic and Social Research, Univ. of Melbourne

$\begin{array}{lll}0.353 & 0.647 & 0.000\end{array}$

Monash Business School, Monash Univ.

$\begin{array}{lll}0.270 & 0.718 & 0.013\end{array}$

National Bureau of Economic Research (NBER)

$\begin{array}{lll}0.288 & 0.045 & 0.667\end{array}$

National Graduate Institute for Policy Studies (GRIPS)

National Research Univ. Higher School of Econ.

Nationalekonomiska Institutionen, Ekonomihögskolan, Lunds Universitet

$\begin{array}{lll}0.000 & 1.000 & 0.000\end{array}$

$\begin{array}{lll}0.000 & 1.000 & 0.000\end{array}$

$\begin{array}{lll}0.000 & 1.000 & 0.000\end{array}$

Nationalekonomiska institutionen, Handelshögskolan, Göteborgs Universitet

$\begin{array}{lll}0.158 & 0.822 & 0.020\end{array}$

Nationalekonomiska Institutionen, Uppsala Universitet

Norges Handelshøyskole (NHH)

$\varnothing$ konomisk Institut, Københavns Universitet

Økonomisk institutt, Universitetet i Oslo

Organisation de Coopération et de Développement Économiques (OCDE)

Paris School of Econ.

Peter G. Peterson Institute for International Econ. (IIE)

$\begin{array}{lll}0.000 & 1.000 & 0.000\end{array}$

$\begin{array}{lll}0.000 & 1.000 & 0.000\end{array}$

$\begin{array}{lll}0.000 & 0.946 & 0.054\end{array}$

$\begin{array}{lll}0.165 & 0.740 & 0.095\end{array}$

$\begin{array}{lll}0.000 & 1.000 & 0.000\end{array}$

$0.480 \quad 0.455 \quad 0.066$

$\begin{array}{lll}0.394 & 0.291 & 0.315\end{array}$

Research and Statistics Group, Federal Reserve Bank of New York

$\begin{array}{lll}0.000 & 0.827 & 0.173\end{array}$

Research Department, International Monetary Fund (IMF)

$0.008 \quad 0.875 \quad 0.116$

Research Division, Federal Reserve Bank of St. Louis

$0.885 \quad 0.000 \quad 0.115$

Research School of Econ., College of Business and Econ., Australian National Univ. $0.270 \quad 0.683 \quad 0.047$

Resources for the Future (RFF)

$\begin{array}{lll}0.241 & 0.717 & 0.042\end{array}$

Rotman School of Management, Univ. of Toronto

$\begin{array}{lll}0.000 & 0.893 & 0.107\end{array}$

School of Business and Econ., Maastricht Univ.

$\begin{array}{lll}0.250 & 0.747 & 0.003\end{array}$

School of Business and Econ., Universidade Nova de Lisboa

$\begin{array}{lll}0.000 & 0.972 & 0.028\end{array}$ 
Table 5 (continued)

Institution

Archetypoid Shares

$1 \quad 2 \quad 3$

School of Business and Econ., Vrije Universiteit Amsterdam

$\begin{array}{lll}0.436 & 0.562 & 0.002\end{array}$

School of Business, Leicester Univ.

School of Econ. and Finance, Queen Mary Univ. of London

School of Econ. and Management, Universiteit van Tilburg

School of Econ. and Political Science, Universität St. Gallen

School of Econ., Faculty of Arts and Social Sciences, Univ. of Sydney

$0.0890 .911 \quad 0.000$

$\begin{array}{lll}0.000 & 0.941 & 0.059\end{array}$

$\begin{array}{lll}0.374 & 0.619 & 0.007\end{array}$

$\begin{array}{lll}0.000 & 0.990 & 0.010\end{array}$

School of Econ., Finance and Management, Univ. of Bristol

$\begin{array}{lll}0.000 & 0.993 & 0.007\end{array}$

School of Econ., Univ. College Dublin

$\begin{array}{lll}0.041 & 0.923 & 0.036\end{array}$

School of Econ., Univ. of Kent

$\begin{array}{lll}0.226 & 0.747 & 0.027\end{array}$

$\begin{array}{llll}0.093 & 0.907 & 0.000\end{array}$

School of Econ., Univ. of Manchester

$\begin{array}{lll}0.245 & 0.732 & 0.024\end{array}$

School of Econ., Univ. of Nottingham

$\begin{array}{llll}0.295 & 0.631 & 0.074\end{array}$

School of Econ., Univ. of Queensland

$\begin{array}{lll}0.404 & 0.596 & 0.000\end{array}$

School of Econ., Univ. of Surrey

School of Econ., UNSW Business School, UNSW Sydney

School of International and Public Affairs (SIPA), Columbia Univ.

School of Management, Yale Univ.

Schweizerische Nationalbank (SNB)

Sciences économiques, Sciences Po

Scuola di Economia e Management, Università degli Studi di Firenze

SKEMA Business School

Sloan School of Management, Massachusetts Institute of Technology (MIT)

$\begin{array}{lll}0.000 & 0.959 & 0.041\end{array}$

$\begin{array}{lll}0.363 & 0.572 & 0.065\end{array}$

$\begin{array}{llll}0.648 & 0.013 & 0.339\end{array}$

$\begin{array}{lll}0.100 & 0.598 & 0.302\end{array}$

$\begin{array}{lll}0.000 & 1.000 & 0.000\end{array}$

$\begin{array}{llll}0.951 & 0.000 & 0.049\end{array}$

$\begin{array}{lll}0.008 & 0.992 & 0.000\end{array}$

$\begin{array}{lll}0.031 & 0.925 & 0.044\end{array}$

$\begin{array}{lll}0.159 & 0.459 & 0.383\end{array}$

Solvay Brussels School of Econ. and Management, Univ. Libre de Bruxelles

$\begin{array}{lll}0.231 & 0.769 & 0.000\end{array}$

Stern School of Business, New York Univ. (NYU)

Sussex Business School, Univ. of Sussex

Tepper School of Business Administration, Carnegie Mellon Univ.

Tinbergen Instituut

Toulouse School of Econ. (TSE)

UN Univ.-Maastricht Economic Research Institute of Innovation and Technology

$\begin{array}{lll}0.050 & 0.598 & 0.352\end{array}$

$\begin{array}{lll}0.181 & 0.809 & 0.010\end{array}$

$\begin{array}{lll}0.089 & 0.779 & 0.132\end{array}$

$\begin{array}{lll}0.658 & 0.312 & 0.030\end{array}$

$\begin{array}{lll}0.248 & 0.683 & 0.069\end{array}$

$\begin{array}{lll}0.075 & 0.921 & 0.004\end{array}$

Università Commerciale Luigi Bocconi

Univ. Paris-Dauphine (Paris IX)

Univ. of Piraeus

UNSW Business School, UNSW Sydney

Vancouver School of Econ., Univ. of British Columbia

Victoria Business School, Victoria Univ. of Wellington

Volkswirtschaftliche Fakultät, Ludwig-Maximilians-Universität München

W.P. Carey School of Business, Arizona State Univ.

Waikato Management School, Univ. of Waikato

Walter A. Haas School of Business, Univ. of California-Berkeley

Warwick Business School, Univ. of Warwick

Wharton School of Business, Univ. of Pennsylvania

Wirtschaftswissenschaftliche Fakultät, Heinriche-Heine-Universität Düsseldorf

$\begin{array}{lll}0.056 & 0.829 & 0.115\end{array}$

$\begin{array}{lll}0.000 & 1.000 & 0.000\end{array}$

$\begin{array}{lll}0.024 & 0.976 & 0.000\end{array}$

$\begin{array}{lll}0.219 & 0.724 & 0.057\end{array}$

$\begin{array}{llll}0.251 & 0.529 & 0.221\end{array}$

$\begin{array}{llll}0.226 & 0.774 & 0.000\end{array}$

$\begin{array}{llll}0.000 & 0.972 & 0.028\end{array}$

$\begin{array}{lll}0.192 & 0.696 & 0.112\end{array}$

$\begin{array}{llll}0.449 & 0.551 & 0.000\end{array}$

$\begin{array}{llll}0.178 & 0.311 & 0.511\end{array}$

$\begin{array}{llll}0.210 & 0.727 & 0.063\end{array}$

$\begin{array}{llll}0.030 & 0.848 & 0.122\end{array}$

$\begin{array}{llll}0.000 & 1.000 & 0.000\end{array}$

Wirtschaftswissenschaftliche Fakultät, Humboldt-Universität Berlin

$\begin{array}{lll}0.000 & 1.000 & 0.000\end{array}$

Wirtschaftswissenschaftliche Fakutät, Universität Zürich

$\begin{array}{lll}0.000 & 0.993 & 0.007\end{array}$ 
Table 5 (continued)

\begin{tabular}{lccc}
\hline Institution & \multicolumn{3}{c}{ Archetypoid Shares } \\
\cline { 2 - 5 } & 1 & 2 & 3 \\
\hline Wirtschaftswissenschaftlicher Fachbereich, Rhein. Friedrich-Wilhelms-Univ. Bonn & 0.000 & 0.939 & 0.061 \\
Woodrow Wilson School of Public and International Affairs, Princeton Univ. & 0.201 & 0.298 & 0.500 \\
World Bank Group & 0.020 & 0.955 & 0.026 \\
WU Wirtschaftsuniversität Wien & 0.072 & 0.928 & 0.000
\end{tabular}

\section{References}

Bolli, T., Olivares, M., Bonaccorsi, A., Daraio, C., Aracil, A. G., \& Lepori, B. (2016). The differential effects of competitive funding on the production frontier and the efficiency of universities. Economics of Education Review, 52, 91-104.

Bornmann, L., \& Wohlrabe, K. (2019). Normalisation of citation impact in economics. Scientometrics, 120(2), 841-884.

Chan, B. H., Mitchell, D. A., \& Cram, L. E. (2003). Archetypal analysis of galaxy spectra. Monthly Notices of the Royal Astronomical Society, 338(3), 790-795.

Cutler, A., \& Breiman, L. (1994). Archetypal analysis. Technometrics, 36(4), 338-347.

Davis, T., \& Love, B. C. (2010). Memory for category information is idealized through contrast with competing options. Psychological Science, 21(2), 234-242.

Epifanio, I. (2016). Functional archetype and archetypoid analysis. Computational Statistics \& Data Analysis, 104, 24-34.

Feld, S., Werner, M., Schönfeld, M., \& Hasler, S. (2015). Archetypes of alternative routes in buildings. In 2015 International conference on indoor positioning and indoor navigation (IPIN) (pp. 1-10). IEEE.

Gnewuch, M., \& Wohlrabe, K. (2018). Super-efficiency of education institutions: an application to economics departments. Education Economics, 26(6), 610-623.

Gralka, S. (2018). Persistent inefficiency in the higher education sector: evidence from Germany. Education Economics, 26(4), 373-392.

Gralka, S., Wohlrabe, K., \& Bornmann, L. (2019). How to measure research efficiency in higher education? Research grants vs publication output. Journal of Higher Education Policy and Management, 41(3), $322-341$.

Hazelkorn, E. (2007). The impact of league tables and ranking systems on higher education decision making. Higher Education Management and Policy, 19(2), 1-24.

Hinrich, J. L., Bardenfleth, S. E., Røge, R. E., Churchill, N. W., Madsen, K. H., \& Mørup, M. (2016). Archetypal analysis for modeling multisubject fMRI data. IEEE Journal of Selected Topics in Signal Processing, 10(7), 1160-1171.

Hsieh, C.-S., Konig, M. D., Liu, X., \& Zimmermann, C. (2018). Superstar Economists: Coauthorship networks and research output. CEPR Discussion Paper, No. DP13239, 1-47.

Johnes, G., \& Johnes, J. (2016). Costs, efficiency, and economies of scale and scope in the English higher education sector. Oxford Review of Economic Policy, 32(4), 596-614.

Moliner, J., \& Epifanio, I. (2018). Bivariate functional archetypoid analysis: an application to financial time series. In Mathematical and statistical methods for actuarial sciences and finance (pp. 473-476). Springer.

Mørup, M., \& Hansen, L. K. (2012). Archetypal analysis for machine learning and data mining. Neurocomputing, 80, 54-63.

Pike, G. R., \& Kuh, G. D. (2005). A typology of student engagement for American colleges and universities. Research in Higher Education, 46(2), 185-209.

Rath, K., \& Wohlrabe, K. (2016). Recent trends in co-authorship in economics: evidence from RePEc. Applied Economics Letters, 23(12), 897-902.

Seiler, C., \& Wohlrabe, K. (2013). Archetypal scientists. Journal of Informetrics, 7(2), 345-356.

Seth, S., \& Eugster, M. J. (2016). Probabilistic archetypal analysis. Machine Learning, 102(1), 85-113.

Steinschneider, S., \& Lall, U. (2015). Daily precipitation and tropical moisture exports across the eastern United States: an application of archetypal analysis to identify spatiotemporal structure. Journal of Climate, 28(21), 8585-8602. 
Sternberg, R., \& Litzenberger, T. (2005). The publication and citation output of German Faculties of Economics and Social Sciences-a comparison of faculties and disciplines based upon SSCI data. Scientometrics, 65(1), 29-53.

Sun, W., Yang, G., Wu, K., Li, W., \& Zhang, D. (2017). Pure endmember extraction using robust kernel archetypoid analysis for hyperspectral imagery. ISPRS Journal of Photogrammetry and Remote Sensing, 131, 147-159.

Thurau, C., Kersting, K., Wahabzada, M., \& Bauckhage, C. (2012). Descriptive matrix factorization for sustainability adopting the principle of opposites. Data Mining and Knowledge Discovery, 24(2), 325-354.

Vinué, Guillermo. (2017). Anthropometry: An R package for analysis of anthropometric data. Journal of Statistical Software, 77(6), 1-39.

Vinué, G., \& Epifanio, I. (2017). Archetypoid analysis for sports analytics. Data Mining and Knowledge Discovery, 31(6), 1643-1677.

Vinué, Guillermo, Epifanio, I., \& Alemany, S. (2015). Archetypoids: A new approach to define representative archetypal data. Computational Statistics and Data Analysis, 87, 102-115.

Wolszczak-Derlacz, J., \& Parteka, A. (2011). Efficiency of European public higher education institutions: a two-stage multicountry approach. Scientometrics, 89(3), 887-917.

Worthington, A. C., \& Higgs, H. (2011). Economies of scale and scope in Australian higher education. Higher Education, 61(4), 387-414.

Zimmermann, C. (2013). Academic rankings with RePEc. Econometrics, 1(3), 249-280. 